\title{
Probing Vietnam's Legal Prospects in the South China Sea Dispute
}

\author{
Hong Kong To Nguyen, Manh Tung Ho, \\ and Quan-Hoang Vuong
}

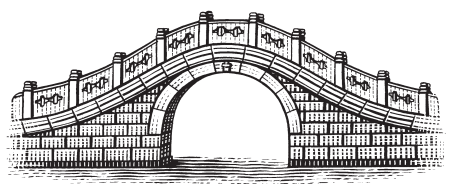

HONG KONG TO NGUYEN is a MEXT Scholar pursuing a doctoral degree in international relations at Ritsumeikan Asia Pacific University (Japan). She is also a researcher affiliated with the Centre for Interdisciplinary Social Research at Phenikaa University (Vietnam). Ms. Nguyen holds a BA in philosophy and political science from Columbia University and an MSc in international relations from Ritsumeikan Asia Pacific University. She can be reached at <hongkong.nguyento@phenikaa-uni.edu.vn>.

MANH TUNG HO is a Research Fellow with the project "Emotional AI in Cities: Cross Cultural Lessons from UK and Japan on Designing for an Ethical Life," funded by the JST-UKRI Joint Call on Artificial Intelligence and Society in 2019. He also is a researcher at the Centre for Interdisciplinary Social Research at Phenikaa University (Vietnam). Mr. Ho holds an MSc in society, culture, and media studies from Ritsumeikan Asia Pacific University. He can be reached at <tung.manhho@phenikaa-uni.edu.vn>.

QUAN-HOANG VUONG is the Director of the Centre for Interdisciplinary Social Research at Phenikaa University (Vietnam). He is the chairman of the Vietnam chapter of the European Association of Science Editors. His main interests are the applications of probability and statistics in economics, management, social medicine, sociocultural systems, and the philosophy of science. He has published more than 160 papers and books with many leading academic publishers. He can be reached at <hoang.vuongquan@phenikaa-uni.edu.vn>. 
This article reviews dispute settlement procedures under the 1982 United Nations Convention on the Law of the Sea (UNCLOS), discusses the application in two cases, and draws implications for the actionable legal procedures available to Vietnam.

\section{MAIN ARGUMENT}

Although most Asian states are signatories to UNCLOS, which offers options for dispute resolution by either voluntary or compulsory processes, in reality fewer than a dozen Asian states have taken advantage of such an approach. The decision to adopt third-party mechanisms comes under great scrutiny and deliberation, not least because of the entailing legal procedures and the politically sensitive nature of disputes. Vietnam claims the second-largest maritime area in the South China Sea dispute after China. A comparison of two recent cases-the arbitration between the Philippines and China and the conciliation between Timor-Leste and Australia-highlights the importance of selecting between binding and nonbinding decisions and framing a complaint. In particular, any legal action under UNCLOS should specify China's claims and actions in areas that encroach on Vietnam's claimed exclusive economic zone (EEZ) and violate international law.

\section{POLICY IMPLICATIONS}

- Were Vietnam to build a case against China in the South China Sea based on maritime entitlements, rather than boundary delimitation, it should initiate a compulsory arbitration procedure pursuant of Article 287 and Annex VII of UNCLOS. In taking this step, Vietnam should seek a ruling regarding (1) entitlements to living and nonliving resources in its EEZ and continental shelf and (2) the legality of China's claims and activities in the South China Sea.

- While Vietnam continues to prefer negotiations, the growing assertiveness of China, including its activities in Vietnam's claimed EEZ, may change this calculation. A potential victory in international arbitration could secure Vietnam's sovereignty over its EEZ and continental shelf. 
$\mathrm{T}$ he South China Sea has long been the world's most contested body of water and an enduring source of tension in Southeast Asia. The disputes, which concern sovereignty over the sea's islands and features and the maritime entitlements associated with them, were first recognized as a flashpoint following a naval clash between Vietnam and China in January 1974. ${ }^{1}$ Since then, the conflict has transformed from a state-to-state territorial dispute to multistate maritime disputes that represent a major threat to regional security and stability. Considering that approximately half of all maritime boundaries in the world are disputed, it is important to understand this kind of conflict and the role of international law in the settlement of maritime boundary disputes. ${ }^{2}$

This article looks at Vietnam's case within the multiparty South China Sea dispute by drawing on existing legal mechanisms provided in the United Nations Convention on the Law of the Sea (UNCLOS) as well as relevant cases. UNCLOS, which was concluded in 1982 and came into force on November 16,1994, is hailed as one of the twentieth century's most important achievements in international law. It is the only internationally accepted legal document to clarify the spatial limits of a system of maritime zones, regulate the passage of ships, protect the marine environment, guarantee freedom of scientific research, and limit exploitation of maritime resources. ${ }^{3}$ While states' decisions to litigate under UNCLOS vary due to jurisdictional certainty or politico-economic interest, they are more likely than ever to pursue litigation for settling maritime disputes. ${ }^{4}$ Simultaneously, it is worth noting that even though most Asian nations are parties to UNCLOS, the dispute settlement mechanism has only been invoked by a small number of them. Taking into account the complexity of drawing, negotiating, and settling maritime boundaries, this article examines legal options for Vietnam, which ratified UNCLOS in 1994, in its ongoing sovereignty and maritime disputes in the South China Sea. In particular, because the disputes involve more than

\footnotetext{
1 Barry Buzan, A Sea of Troubles? Sources of Dispute in the New Ocean Regime, Adelphi Paper 18, no. 143 (London: International Institute for Strategic Studies, 1978).

2 Victor Prescott and Clive Schofield, The Maritime Political Boundaries of the World, 2nd ed. (Leiden: Brill-Nijhoff, 2004); and Andrew Cannon, "The Impact of Sovereignty and Boundary Disputes on Commercial Investments," Herbert Smith Freehills, July 1, $2016 \approx$ https://www.herbertsmithfreehills. com/latest-thinking/the-impact-of-sovereignty-and-boundary-disputes-on-commercial-investments.

3 United Nations, "United Nations Convention on the Law of the Sea," December 10, $1982 \approx$ https:// www.un.org/depts/los/convention_agreements/texts/unclos/unclos_e.pdf.

4 Md. Saiful Karim, "Litigating Law of the Sea Disputes Using the UNCLOS Dispute Settlement System," in Litigating International Law Disputes: Weighing the Options, ed. Natalie Klein (Cambridge: Cambridge University Press, 2014), 260-83.
} 
two states, the question arises as to whether litigation like that the Philippines pursued in 2013 is feasible for Vietnam.

The article is organized as follows:

$\propto$ pp. 108-13 briefly explain the South China Sea disputes and Vietnam's position.

$\approx$ pp. 113-18 revisit the substance of UNCLOS with regard to maritime boundary delimitation and dispute resolution.

$\therefore$ pp. 118-26 examine the arbitration case between the Philippines and China and the conciliation between Timor-Leste and Australia.

$\approx$ pp. 126-31 identify insights and legal actions from these cases that are relevant to Vietnam and argue that understanding the legal and related dispute-resolution options from Vietnam's perspective is a prerequisite to projecting what actions a major disputing party in the South China Sea case might take in the near future.

$\propto$ p. 131 provides a conclusion.

THE SOUTH CHINA SEA DISPUTES

\section{Who Claims What?}

The decades-long South China Sea territorial and maritime disputes involve diverging claims over the sovereignty of islands and waters among six political entities: Brunei, the People's Republic of China (hereafter China), Malaysia, the Republic of China (hereafter Taiwan), the Philippines, and Vietnam (see Figure 1). ${ }^{5}$ Of the two major archipelagic structures in the South China Sea, all or some of the Spratly Islands are claimed by all six entities, while the Paracel Islands have been occupied by China since 1974 and are claimed by Taiwan and Vietnam. ${ }^{6}$ In a nutshell, China and Taiwan maintain the largest overlapping claims, followed by Vietnam. Meanwhile, the Philippines claims

\footnotetext{
5 While some experts consider Indonesia a claimant state in the South China Sea in light of its exclusive economic zone around the Natuna Islands that intersects with China's nine-dash line claim, the Indonesian foreign ministry holds that the country is a nonclaimant state and has no overlapping jurisdiction with China. "Indonesia Rejects China's Claims over South China Sea," Reuters, January 1, $2020 \approx$ https://www.reuters.com/article/us-indonesia-chinasouthchinasea-idUSKBN1Z01RE; and Aaron L. Connelly, "Indonesia in the South China Sea: Going It Alone," Lowy Institute, December 5, $2016 \approx$ https://www.lowyinstitute.org/publications/ indonesia-south-china-sea-going-it-alone.

6 This article uses English-language names for disputed South China Sea features to avoid any appearance of bias. Although names are not the basis for determining sovereignty, the naming of maritime features and zones, especially disputed ones, has long been a way for parties to date and defend their claims. For instance, Vietnam refers to the South China Sea as the "East Sea" (Biển Đông) and has Vietnamese-language names for the Spratly Islands (Trường Sa) and Paracel Islands (Hoàng Sa).
} 
only the Spratly's western area, and Brunei and Malaysia have similarly limited claims over parts of the Spratlys closest to their respective coasts.

The legitimacy of China's claim, best known as the "U-shaped line" or the "nine-dash line," is contested because of its ambiguity. According to

\section{FIGURE 1}

\section{Overlapping Claims in the South China Sea}

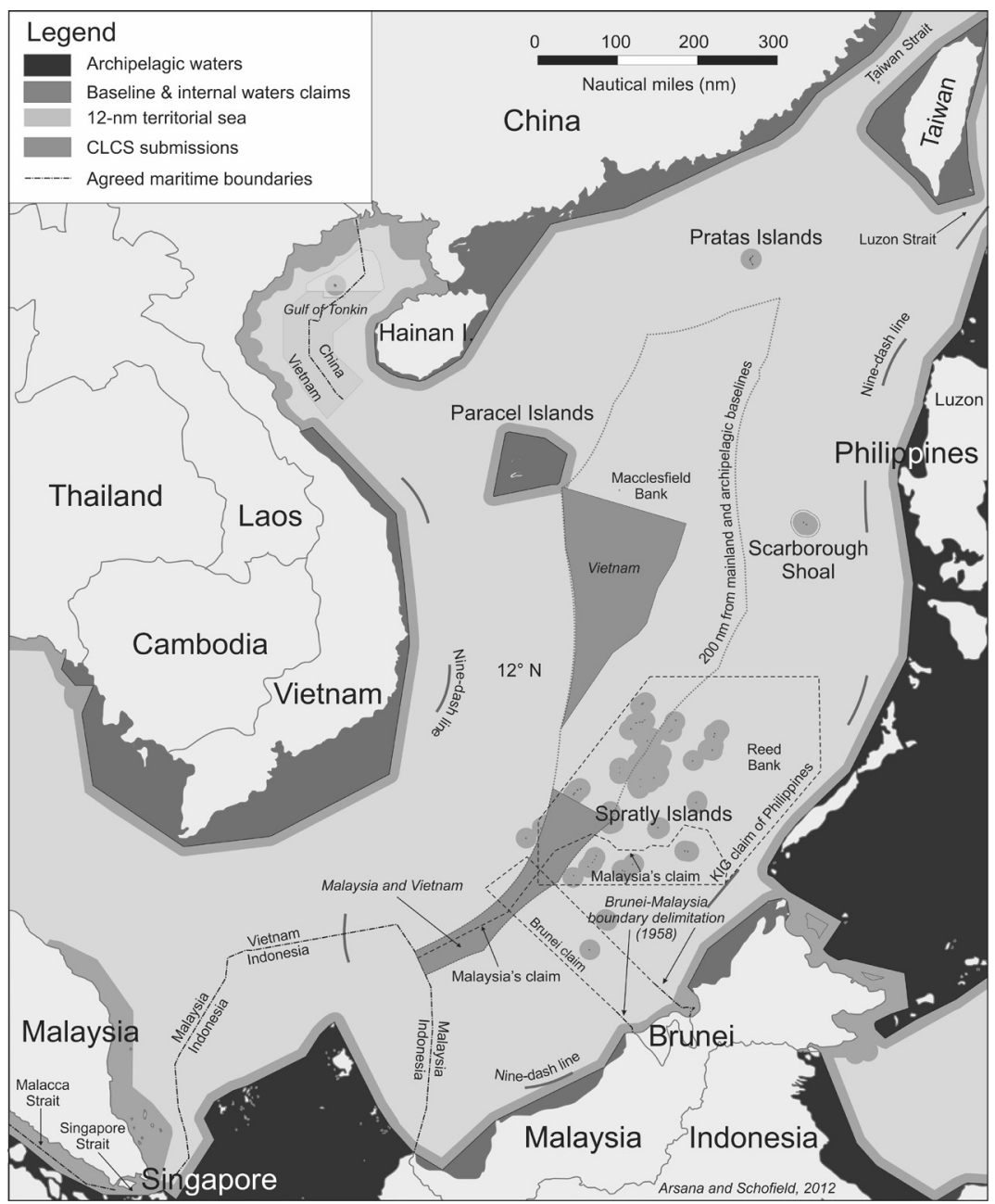

Source: Clive Schofield, "The Regime of Islands Reframed: Developments in the Definition of Islands and their Role in the Delimitation of Maritime Boundaries under the International Law of the Sea," Brill Research Perspectives in the Law of the Sea, no. 1-2 (2021): 39. Reprinted with permission of the author.

Note $\approx$ This map is for representational and illustrative purposes only and does not represent accurate geographic boundaries and maritime lines. 
Zhiguo Gao, China's judge on the International Tribunal for the Law of the Sea (ITLOS) since 2008, "the boundary line on the Chinese map is merely a line that delineates ownership of islands rather than a maritime boundary in the conventional sense." The origin of this line dates back to as early as 1914, when private cartographers first drew a continuous boundary enclosing part of the South China Sea, ${ }^{8}$ and later to a 1935 map published by the Kuomintang government. ${ }^{9}$ A different account suggests a much later date: a line officially drawn by Taiwan in 1947 that China adopted in $1949 .{ }^{10}$

To this day, no official Chinese documents have clarified whether the nine-dash line encompasses all water and land features, including islands, or whether it is some form of unilateral maritime boundary indicator. This aspect is important because according to "the land dominates the sea" principle in international law, maritime claims must be derived from land features. In China's case, the delineated area is not based on any claimed land features and arguably has no land-based sovereign rights. ${ }^{11}$

\section{Who Declares What?}

In terms of legal action, besides the South China Sea arbitration initiated by the Philippines in 2013, there have been a number of important document submissions to the United Nations and its relevant bodies. The first flurry of diplomatic exchanges concerned submissions in the early 2000s to the Commission on the Limits of the Continental Shelf (CLCS)-one of the scientific bodies created under UNCLOS in accordance with Article 76-on the outer limits of the continental shelf beyond 200 nautical miles. ${ }^{12}$ Indonesia and the Philippines were the first two countries to make partial submissions to the CLCS (though not directly related to the South China Sea), all the while reserving their rights to make submissions for other areas of the continental

\footnotetext{
7 Zhiguo Gao, “The South China Sea: From Conflict to Cooperation?” Ocean Development \& International Law 25, no. 3 (1994): 345-59.

8 Zhiguo Gao and Bing Bing Jia, "The Nine-Dash Line in the South China Sea: History, Status, and Implications," American Journal of International Law 107, no. 1 (2013): 98-123.

9 Peter Dutton, “Three Disputes and Three Objectives-China and the South China Sea," Naval War College Review 64, no. 4 (2011): 42-67.

10 Chris P.C. Chung, "Drawing the U-Shaped Line: China’s Claim in the South China Sea, 1946-1974," Modern China 42, no. 1 (2015): 38-72.

11 Jeffrey A. Bader, “The U.S. and China’s Nine-Dash Line: Ending the Ambiguity,” Brookings Institution, February 6, $2014 \odot$ https://www.brookings.edu/opinions/the-u-s-and-chinas-ninedash-line-ending-the-ambiguity.

12 CLCS, "Purpose, Functions and Sessions" $\sim$ https://www.un.org/Depts/los/clcs_new/commission_ purpose.htm\#Purpose.
} 
shelf in conformity with Article 76 and Annex I, "Rules of Procedure and the Scientific and Technical Guidelines of the Commission." ${ }^{13}$

However, the turning point was a joint submission made by Malaysia and Vietnam on May 6, 2009, relating to a southern area in the South China Sea. ${ }^{14}$ One day later, on May 7, Vietnam made an individual partial submission to the CLCS claiming an extended continental shelf in the area northeast of its joint submission with Malaysia (see Figure 1). ${ }^{15}$ In essence, the two submissions measure the outer limit of the continental shelf from mainland territory, not from any of the contested islands in the South China Sea. Given the uncertain legal status of many features in the sea, such positions allow Malaysia and Vietnam to separate the issue of extended continental shelf limits from sovereignty disputes over islands or rocks that would be incapable of generating an exclusive economic zone (EEZ) or continental shelf rights. ${ }^{16}$

At the present rate that the CLCS is managing the submissions, coupled with the substantial number yet to be reviewed, the joint submission is unlikely to be considered for some years or even decades. Furthermore, the commission could be tied up indefinitely from objections raised by both China and the Philippines. In two notes verbales sent to the UN secretary-general on May 7, 2009, China declared that it "has indisputable sovereignty over the islands in the South China Sea and the adjacent waters, and enjoys sovereign rights and jurisdiction over the relevant waters as well as the seabed and subsoil thereof." 17 The ambiguous wording caused more controversy than

13 CLCS, "Outer Limits of the Continental Shelf beyond 200 Nautical Miles from the Baselines: Submissions to the Commission: Submission by the Republic of Indonesia," February 1, $2012 \approx$ https://www.un.org/Depts/los/clcs_new/submissions_files/submission_idn.htm; and CLCS, "Outer Limits of the Continental Shelf beyond 200 Nautical Miles from the Baselines: Submissions to the Commission: Submission by the Republic of the Philippines," July 19, $2012 \propto$ https://www.un.org/ Depts/los/clcs_new/submissions_files/submission_phl_22_2009.htm.

14 CLCS, "Outer Limits of the Continental Shelf beyond 200 Nautical Miles from the Baselines: Submissions to the Commission: Joint Submission by Malaysia and the Socialist Republic of Viet Nam," May $2009 \curvearrowright$ https://www.un.org/Depts/los/clcs_new/submissions_files/submission_ mysvnm_33_2009.htm.

15 Socialist Republic of Vietnam, "Submission to the Commission on the Limits of the Continental Shelf Pursuant to Article 76, Paragraph 8 of the United Nations Convention on the Law of the Sea 1982: Partial Submission in Respect of Vietnam's Extended Continental Shelf: North Area (VNM-N)," May $2009 \approx$ https://www.un.org/Depts/los/clcs_new/submissions_files/vnm37_09/vnm2009n_ executivesummary.pdf.

16 Robert Beckman, “The South China Sea: Worsening Dispute or Growing Clarity in Claims?” in Strategic Currents: Issues in Human Security in Asia, ed. Yang Razali Kassim (Singapore: ISEAS Publishing, 2011), 172-74.

17 Permanent Mission of the People's Republic of China to the United Nations, "Note Verbale No. CML/17/2009," May 7, $2009 \approx$ https:/www.un.org/Depts/los/clcs_new/submissions_files/ mysvnm33_09/chn_2009re_mys_vnm_e.pdf; and Permanent Mission of the People's Republic of China to the United Nations, "Note Verbale No. CML/18/2009," May 7, $2009 \approx$ https://www. un.org/Depts/los/clcs_new/submissions_files/vnm37_09/chn_2009re_vnm.pdf. 
clarification, leaving questions as to whether "adjacent waters" and "relevant waters" meant China's territorial sea. ${ }^{18}$

Obscurity can also be found in China's demand to exercise its alleged "historic rights" in the South China Sea. The foundation for unilateral national claims and exclusive jurisdiction over a sea area on an alleged historical basis is laid out in a study by the UN Secretariat. ${ }^{19}$ According to the study, three factors must be met: "(1) the exercise of authority over the area by the State claiming the historic title; (2) the continuity of this exercise of authority; and (3) the attitude of foreign States." ${ }^{20}$ In analyzing the validity of China's historic rights under international law, it would be difficult for China to prove (1) its effective exercise of authority over the enclosed area, (2) the continuity of such authority over a period as long as 50 years, and (3) that it had gained the recognition and acceptance of foreign (i.e., neighboring) states. ${ }^{21}$

In response to the case initiated by the Philippines on January 22, 2013, the Permanent Court of Arbitration (PCA) at The Hague issued a ruling in July 2016 rejecting China's nine-dash line claim of historic rights in the South China Sea, and thus finding that China has no legal basis for claiming rights to this maritime area. ${ }^{22}$ This ruling was the first detailed international judicial interpretation of these key aspects of UNCLOS and international law of the sea at large. Despite China's nonappearance and nonparticipation, the case was allowed to proceed in the form of "compulsory procedures entailing binding decisions" following Part XV, Section 2 of UNCLOS, to which both China and the Philippines are parties. Although Vietnam did not intercede or participate in the arbitration, the process and outcome are clearly of interest to Vietnam and can provide insight into whether it too should file an international arbitration case. ${ }^{23}$

18 Robert Beckman, "South China Sea: How China Could Clarify Its Claims," S. Rajaratnam School of International Studies, September 16, $2010 \curvearrowright$ https://www.rsis.edu.sg/wp-content/uploads/2014/07/ CO10116.pdf.

19 United Nations, "Juridical Regime of Historic Waters Including Historic Bays-A Study Prepared by the Secretariat," document no. A/CN.4/143, March 9, $1962 \approx$ https://legal.un.org/ilc/ documentation/english/a_cn4_143.pdf.

20 Ibid.

21 Masahiro Miyoshi, "China’s 'U-Shaped Line' Claim in the South China Sea: Any Validity Under International Law?” Ocean Development \& International Law 43, no. 1 (2012): 1-17.

22 Permanent Court of Arbitration (PCA), "The South China Sea Arbitration (The Republic of Philippines v. The People's Republic of China), Award," PCA case no. 2013-19, July 12, 2016 \& https://pca-cpa.org/en/cases/7.

23 Mark J. Valencia, “Should Vietnam Take China to Arbitration over the South China Sea?" Lawfare, August 18, $2020 \approx$ https://www.lawfareblog.com/should-vietnam-take-china-arbitration-oversouth-china-sea; and David Hutt, "Vietnam May Soon Sue China on South China Sea," Asia Times, May 7, $2020 \curvearrowright$ https://asiatimes.com/2020/05/vietnam-may-soon-sue-china-on-south-china-sea. 
Another important development was the round of diplomatic exchanges in early 2020 following a new partial submission to the CLCS by Malaysia concerning an extended continental shelf in the northern part of the South China Sea. ${ }^{24}$ The move, which is a continuation of the CLCS submissions made ten years earlier, clarifies the possible overlapping claims of Malaysia, Vietnam, and the Philippines. All three countries hold that none of the features in the Spratly Islands are capable of generating an EEZ or a continental shelf. In response, China protested that the submission infringed on its sovereignty, sovereign rights, and jurisdiction, claims that were once again met with objections from the Philippines and Vietnam.

This section has examined the claims and positions of key claimant parties in the South China Sea dispute. The next section looks more closely at UNCLOS and reviews two relevant cases-the South China Sea arbitration between the Philippines and China and the Timor Sea conciliation between Timor-Leste and Australia-to identify potential legal actions for Vietnam regarding its maritime boundaries and entitlements.

\section{UNDERSTANDING MARITIME DISPUTE SETTLEMENT UNDER UNCLOS}

The delineation and delimitation of maritime space, which was once considered outside territorial jurisdiction, have generated significant interest worldwide since $1945 .^{25}$ When UNCLOS was signed in 1982, coastal states were granted sovereign rights over a 200-nautical-mile EEZ with respect to natural resources and certain economic and research activities. ${ }^{26}$ As a result, the rights over a maritime zone much larger than the 12-nautical-mile territorial sea also designated by the convention have increased disputes and the risk of conflict. The introduction of an official law governing the oceans clarified the distinction between maritime rights and maritime delimitation even though the two are closely related. This section focuses on two crucial aspects of UNCLOS: boundary delimitation and dispute settlement procedures.

\footnotetext{
24 Government of Malaysia, "Malaysia Partial Submission to the Commission on the Limits of the Continental Shelf Pursuant to Article 76, Paragraph 8 of the United Nations Convention on the Law of the Sea 1982 in the South China Sea," November $2017 \approx$ https://www.un.org/Depts/los/ clcs_new/submissions_files/mys85_2019/20171128_MYS_ES_DOC_001_secured.pdf.

25 Gerald H. Blake, ed., Maritime Boundaries: World Boundaries, vol. 5 (London: Routledge, 2016).

26 United Nations, "United Nations Convention on the Law of the Sea."
} 


\section{Delimitation of Maritime Boundaries and Maritime Rights}

Regarding delimitation, UNCLOS retains the indeterminate concept of "equidistance plus special circumstances" for maritime boundaries in a territorial sea, but drops this language in the case of continental shelf and EEZ boundaries. The change in language, which concerns a particular method of delimitation, shifts the delimitation basis from the median or equidistant lines to "equitable solutions." 27 The notion of equitable solutions originated in the 1945 Truman proclamation on U.S. policy toward the continental shelf regarding delimitation. ${ }^{28}$ Questions, however, abound concerning the vagueness of "equitable principles," which do not explicitly outline criteria for achieving an equitable result. As geographic features in each case vary widely, there is no equitable principle in maritime delimitation that can be applied to all cases, but rather equitable results must be arrived at on a case-by-case basis. In fact, although the International Court of Justice (ICJ), the UN's principal judicial organ, has reiterated that the equidistance method of delimitation is not the preferred method, the court has continued to apply it in delimiting boundaries. ${ }^{29}$

In addition to the delimitation principle, UNCLOS outlines different rules for different maritime zones such as territorial seas, EEZs, and the high seas beyond national jurisdiction (see Figure 2). In particular, states have full sovereign jurisdiction over internal waters, which include historic bays and all waters landward of the baseline, such as lakes, rivers, and tidewaters. The maritime area adjacent to the coast of a state, extending seaward up to 12 nautical miles from its baseline is its territorial sea, in which a state is granted absolute sovereignty and exclusive rights to fisheries and mineral resources. UNCLOS provides the right of innocent passage for foreign vessels to travel through other countries' territorial seas without entering their internal waters. In the case of an archipelagic state, the state's sovereignty extends beyond its archipelagic waters to cover the adjacent 12-nautical-mile territorial sea (Part II, Section 1, Article 2, and Part IV). The contiguous zone is an area abutting the territorial sea that extends seaward no more than 24 nautical miles from the baseline. As Article 33 stipulates, in the contiguous zone a

\footnotetext{
27 United Nations, "United Nations Convention on the Law of the Sea."

28 Michael P. Scharf, "The Truman Proclamation on the Continental Shelf," in Customary International Law in Times of Fundamental Change: Recognizing Grotian Moments, ed. Michael P. Scharf (Cambridge: Cambridge University Press, 2013), 107-22.

29 Fayokemi Olorundami, "The ICJ and Its Lip Service to the Non-priority Status of the Equidistance Method of Delimitation," Cambridge Journal of International and Comparative Law 4, no. 1 (2015): 53-72.
} 


\section{FIGURE 2}

\section{Maritime Zones and Rights under UNCLOS}

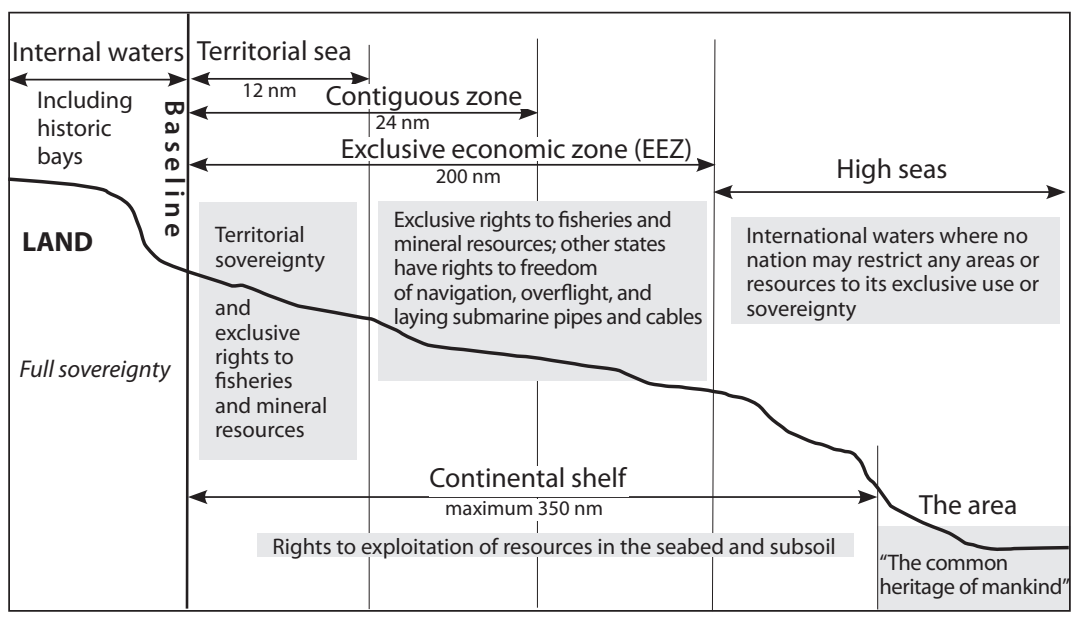

Source: Compiled by the authors based on UNCLOS and a summary of sovereign rights by Rebecca Strating, "Maritime Disputes, Sovereignty and the Rules-Based Order in East Asia," Australian Journal of Politics and History 65, no. 3 (2019): 449-65, doi: https://doi.org/10.1111/ajph.12588.

coastal state may "exercise the control necessary to prevent infringement" or "punish infringement" committed within its territory or territorial sea. An EEZ, under Article 57, will "not extend beyond 200 nautical miles from the baselines from which the breadth of the territorial sea is measured." 30 Meanwhile, the high seas are waters where no nation may restrict access or exclusively claim areas, resources, or sovereignty.

According to Article 121, only an island defined as "a naturally formed area of land, surrounded by water, which is above water at high tide," generates the maritime rights of a territorial sea with an EEZ. Meanwhile, rocks-understood as land permanently above water but unable to sustain habitation or life on their own-generate a 12-nautical-mile maritime zone but no EEZ. Artificial islands are not considered to possess the status of islands under Article 60, and thus are not granted maritime rights. Additionally, reclaimed landmasses can generate broad maritime claims-including 200-nautical-mile EEZs_but in a maritime delimitation

30 United Nations, "United Nations Convention on the Law of the Sea," Part V. 
scenario the opposing coastal state might not accept the new and advanced position of the reclaiming state. Besides these basic principles, many other technical factors, ranging from geographic, geodetic, hydrographic, and cartographic, are required in the delimitation of maritime boundaries.

\section{Dispute Settlement Scheme}

According to Part XV of UNCLOS, there are two categories for dispute settlement procedures: nonbinding and binding. Nonbinding, or voluntary procedures, are traditional, consent-based, peaceful settlement procedures involving negotiation, consultation, or conciliation, whereas binding, or compulsory procedures, require a binding third-party settlement. By becoming parties to UNCLOS, nation-states automatically consent to the convention's dispute resolution provisions. Prior to binding procedures, parties must have recourse to alternative methods of dispute settlement (e.g., voluntary, peaceful procedures). ${ }^{31}$ Section 1 of Part XV permits states to use a range of peaceful methods, including settlement under separate agreements, and highlights the continuing relevance of traditional, consent-based modes of dispute resolution in the interpretation and application of UNCLOS. Dispute claimants are obliged to exchange views, negotiate, and settle through diplomatic channels. Annex $\mathrm{V}$ touches on a separate procedure of conciliation if no settlement is reached by the parties.

In case of binding or compulsory proceedings, Part XV, Article 287, stipulates that the concerned parties may choose one of the four following forums for dispute settlement: (1) ITLOS, which is the Hamburg-based international tribunal created in 1982 in accordance with Annex VI, (2) the ICJ, (3) an arbitral tribunal in accordance with Annex VII, or (4) a special arbitral tribunal in accordance with Annex VII. When no choice has been made, or no common choice is agreed on, then Annex VII arbitration-under the auspices of the PCA-is the default forum for settlement per Article 287. Since the convention entered into force in 1994, the PCA has arbitrated 13 cases under Annex VII, including the one between the Philippines and China ${ }^{32}$ whereas ITLOS has adjudicated 29 cases. $^{33}$

There are two crucial differences between the PCA and ITLOS: only the former is authorized for compulsory jurisdiction, while only the latter can

\footnotetext{
31 United Nations, "United Nations Convention on the Law of the Sea."

32 PCA, “The South China Sea Arbitration (The Republic of Philippines v. The People's Republic of China), Award."

33 ITLOS, "List of Cases" $\approx$ https://www.itlos.org/en/main/cases/list-of-cases.
} 
respond to emergent requests at all times. ${ }^{34}$ On the one hand, the variety of forums for compulsory settlement under UNCLOS accommodates states' disparate preferences, as some may oppose a particular form of judicial settlement. Concerning maritime delimitation, there is indeed consistent use across the ICJ, ITLOS, and arbitral tribunal. On the other hand, this results in fragmentation in terms of both the lack of a single authoritative forum for settling disputes under UNCLOS and an absence of uniformity in the outcomes of similar cases before different forums. ${ }^{35}$ However, arbitration can be deemed the default compulsory mode unless concerned parties agree otherwise.

Additionally, Part XV, Section 3, Article 298(1.a) allows parties to declare that they do not accept one or more of the compulsory procedures entailing binding decisions as stipulated in Part XV, Section 2. In essence, a state may opt out of compulsory procedures with respect to disputes over "the sea boundary delimitations, or those involving historic bays," and "military activities," provided that it "accept[s] submission of the matter to conciliation under Annex V, Section 2." This means that any state making an Article 298 declaration is obliged to submit to conciliation (see Figure 3). Note that in the

FIGURE 3

A Summary of the Dispute Settlement Procedures under UNCLOS

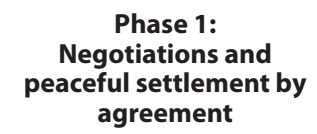

Phase 1: agreement
Phase 2: Compulsory arbitration entailing binding decisions

\section{Nonbinding compulsory conciliation \\ Phase 3:}

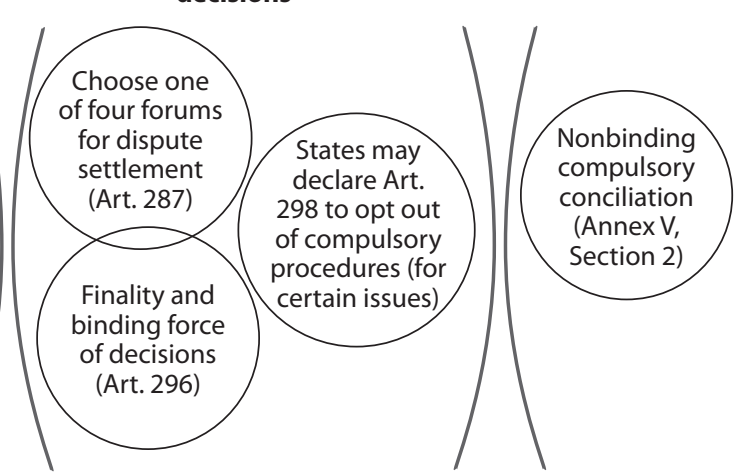

34 Dai Tamada, “The UNCLOS Dispute Settlement Mechanism: Effectiveness and Limitations," Kobe University Law Review 51, no. 3 (2018): 24-39.

35 Alan E. Boyle, "Dispute Settlement and the Law of the Sea Convention: Problems of Fragmentation and Jurisdiction," International and Comparative Law Quarterly 46, no. 1 (1997): 37-54. 
third phase, as long as the parties to the dispute are signatories of UNCLOS, any party can initiate the compulsory conciliation without gaining the other disputing party's consent. The compulsory nature of this proceeding, also known as "unilateral referral," is supported by Articles 297-98 and Annex V.

\section{POINTS OF REFERENCE}

This section discusses key points in both the South China Sea case and the Timor Sea case. Though there are fundamental differences in the cases regarding the dispute history and number of claimants, the justification for selecting them is as follows. First, both cases mark contention over maritime boundaries related to an EEZ and continental shelf of the claimant states (the Philippines and Timor-Leste). Second, the respondent states (China and Australia) have both made the declaration to exclude disputes concerning maritime delimitation from compulsory procedures entailing binding decisions as outlined in Part XV (2.298). Third, the disputing parties in both cases remain tangled up in the complexity of geopolitics and economics, including unresolved questions over the sharing of large reserves of oil and gas in the disputed waters.

\section{The Philippines v. China: The South China Sea Arbitration (2013-16)}

The Philippines ratified UNCLOS on May 8, 1984, and China ratified it on June 7, 1996. Key events of the case are summarized as follows. On January 22, 2013, the Philippines instituted a compulsory arbitration procedure against China under Article 287 and Annex VII of UNCLOS. On February 19, 2013, China categorically rebuffed the Philippines' move to commence arbitral proceedings, returning the note and the notification and refusing to appoint an arbitrator as required under Article 3 of Annex VII. The proceeding was allowed to go ahead for several reasons: (1) the Philippines proved that a long history of peaceful negotiations had failed and all options had been exhausted, (2) Part XV, Section 2, of UNCLOS allows for compulsory procedures entailing binding decisions, and (3) neither party declared their choice of judicial preference per Article 287.

It is worth noting that the Philippines carefully crafted its submissions to avoid territorial sovereignty issues and deal only with UNCLOS jurisdiction issues. It was also aware of the Chinese declaration in August 2006 on excluding maritime boundary delimitations and military activities in 
accepting the convention's compulsory dispute settlement. ${ }^{36}$ In legal terms, the Philippines argued that there exists an "entitlement dispute," which is different and separate from a dispute over territorial sovereignty or maritime delimitation. If the dispute had been over one or both of these, no compulsory procedures under Annex VII could be carried out. Additionally, because Article 9 of Annex VII states that the "[a]bsence of a party or failure of a party to defend its case shall not constitute a bar to the proceedings," the nonparticipation of China did not prevent the case from continuing.

On October 29, 2015, an arbitral tribunal constituted under Annex VII (i.e., the PCA) announced its jurisdiction over seven (out offifteen) submissions from the Philippines concerning Chinese activities and the status of certain features in the South China Sea. ${ }^{37}$ The other submissions have been reserved for the merits stage, which will require the tribunal to investigate the facts and legal justifications in order to decide on the nature and validity of the claims made by the Philippines and China. In the document outlining its jurisdiction, the tribunal distinguished entitlement to maritime zones and delimitation of such zones in an area where parties' entitlements overlap. ${ }^{38}$ In particular, it stated that "a dispute over claimed entitlements may exist even without overlap, where-for instance-a State claims maritime zones in an area understood by other States to form part of the high seas or the Area for the purposes of the Convention." 39

This is not to say China made no response. On December 7, 2014, just a week before the tribunal's deadline for China to submit its counter-memorial, the Ministry of Foreign Affairs instead published the "Position Paper of the Government of the People's Republic of China on the Matter of Jurisdiction in the South China Sea Arbitration Initiated by the Republic of the Philippines." The paper listed three main reasons that the tribunal does not have jurisdiction over the case: (1) the subject matter of the arbitration concerned the territorial sovereignty over different maritime features in the South China Sea, which lies beyond the scope of UNCLOS, (2) China and the Philippines had agreed to settle relevant disputes through negotiation, evidenced in bilateral agreements as well as the 2002 Declaration on the Conduct of Parties in the South China Sea (DOC) of the Association of

\footnotetext{
36 PCA, “The South China Sea Arbitration (The Republic of Philippines v. The People's Republic of China), Award on Jurisdiction and Admissibility," PCA case no. 2013-19, October 29, 2015 × https://pcacases.com/web/sendAttach/2579.

37 Ibid.

38 Ibid.

39 Ibid.
} 
Southeast Asian Nations (ASEAN), and (3) the subject matter was largely concerned with maritime delimitation between the two parties, which falls within the scope of Chinese declaration. ${ }^{40}$

On July 12, 2016, the PCA issued its ruling on the case in favor of fourteen of the fifteen submissions by the Philippines (see Table 1). The PCA award is a legal victory for the Philippines and carries strategic implications for other claimants to the South China Sea, including Vietnam. The decision effectively rules out China's claim of historic rights over waters and islands in the South China Sea enclosed in its nine-dash line and re-examines the legal status of maritime features. China's nonparticipation and dismissal of the case may hinder the ruling's enforcement but did not affect the final decision. This is because under UNCLOS Article 296 and Article 9 of Annex VII, regardless of whether China participates in the tribunal, as long as the proceeding ensures its jurisdiction over the case and that the Philippines' claim has legal and factual grounds, the ruling will be final and binding for both parties.

\section{Timor-Leste v. Australia: The Timor Sea Conciliation (2016-18)}

In 2002, Timor-Leste gained independence from Indonesia and in the next few years inked two major maritime border agreements with Australia to its south. Beyond establishing maritime boundaries, the key issue in the Timor Sea was rights to the area's natural resources-in particular the Greater Sunrise field, which possesses significant gas and oil reserves. The first agreement was the 2002 Timor Sea Treaty, which granted Timor-Leste 90\% of the revenues from petroleum production in the Joint Petroleum Development Area (JPDA) (see Figure 4). ${ }^{41}$ Additionally, the initial production-sharing formula in the Greater Sunrise gas field allocated $20.1 \%$ to the JPDA and 79.9\% to Australia. The second agreement was the 2006 Treaty on Certain Maritime Arrangements in the Timor Sea (CMATS), which administered an equal distribution of revenue in the Greater Sunrise field plus a 50-year moratorium on negotiations over permanent maritime boundaries. ${ }^{42}$

\footnotetext{
40 Ministry of Foreign Affairs of the People's Republic of China, "Position Paper of the Government of the People's Republic of China on the Matter of Jurisdiction in the South China Sea Arbitration Initiated by the Republic of the Philippines," December 7, $2014 \sim$ https://www.fmprc.gov.cn/ nanhai/eng/snhwtlcwj_1/t1368895.htm.

41 Government of Australia and Government of Timor-Leste, “Timor Sea Treaty," May 20, 2002 \& http://www.austlii.edu.au/au/other/dfat/treaties/2003/13.html.

42 Government of Australia and Government of Timor-Leste, "Treaty between the Government of Australia and the Government of the Democratic Republic of Timor-Leste on Certain Maritime Arrangements in the Timor Sea," January 12, $2006 \approx$ http://www.austlii.edu.au/au/other/dfat/ nia/2007/4.html.
} 
TABLE 1

Summary of the Fifteen Philippine Submissions to the Tribunal

\begin{tabular}{|c|c|c|c|}
\hline $\begin{array}{l}\text { Requested rulings } \\
\text { by the Philippines }\end{array}$ & Content & $\begin{array}{l}\text { Tribunal } \\
\text { jurisdiction }\end{array}$ & $\begin{array}{l}\text { Tribunal rulings } \\
\text { (14 out of } 15 \\
\text { in favor of the } \\
\text { Philippines) }\end{array}$ \\
\hline Submissions 1-2 & $\begin{array}{l}\text { UNCLOS governs } \\
\text { China's rights and } \\
\text { obligations in } \\
\text { the South China } \\
\text { Sea-China's } \\
\text { claims of "historic } \\
\text { rights," including } \\
\text { sovereign rights and } \\
\text { jurisdiction, within } \\
\text { its nine-dash line } \\
\text { are invalid. }\end{array}$ & $\begin{array}{l}\text { Reserved for the } \\
\text { merits stage. }\end{array}$ & $\begin{array}{l}\text { China's claims } \\
\text { violate international } \\
\text { law. }\end{array}$ \\
\hline Submissions 3-7 & $\begin{array}{l}\text { Certain features in } \\
\text { the South China } \\
\text { Sea are not islands } \\
\text { under Article } 121(2- \\
\text { 3) of UNCLOS and } \\
\text { are not entitled to } \\
\text { a continental shelf } \\
\text { and a 200-nautical- } \\
\text { mile EEZ. }\end{array}$ & $\begin{array}{l}\text { Jurisdiction over } 3 \text {, } \\
4,6 \text {, and } 7 ; \text { while } 5 \\
\text { is reserved for the } \\
\text { merits stage. }\end{array}$ & $\begin{array}{l}\text { The Spratly Islands } \\
\text { are incapable of } \\
\text { generating an } \\
\text { extended maritime } \\
\text { zone. }\end{array}$ \\
\hline Submissions 8-14 & $\begin{array}{l}\text { China violated } \\
\text { UNCLOS by building } \\
\text { artificial islands, } \\
\text { harming the marine } \\
\text { environment, and } \\
\text { interfering with the } \\
\text { Philippines' rights } \\
\text { concerning resource } \\
\text { exploitation and } \\
\text { navigation. }\end{array}$ & $\begin{array}{l}\text { Jurisdiction over } 10, \\
11, \text { and } 13 ; \text { while } \\
8,9,12 \text {, and } 14 \text { are } \\
\text { reserved for the } \\
\text { merits stage. }\end{array}$ & $\begin{array}{l}\text { Chinese reclamation } \\
\text { and construction } \\
\text { projects on land } \\
\text { features in the } \\
\text { disputed waters } \\
\text { infringe on the } \\
\text { Philippines' } \\
\text { territorial rights } \\
\text { as well as destroy } \\
\text { the marine } \\
\text { environment. }\end{array}$ \\
\hline Submission 15 & $\begin{array}{l}\text { China must "desist } \\
\text { from further } \\
\text { unlawful claims and } \\
\text { activities." }\end{array}$ & None. & None. \\
\hline
\end{tabular}

Yet, by 2012, Timor-Leste was already pursuing a delimitation of maritime boundaries with Australia, essentially trying to extricate itself from CMATS.

On April 11, 2016, Timor-Leste initiated a compulsory, nonbinding conciliation proceeding against Australia in relation to their maritime boundary in the Timor Sea. Within two years, the parties reached an agreement, signed a settlement treaty, and concluded the conciliation at an 
unprecedented pace characterized by transparency and efficiency. ${ }^{43}$ Figure 5 shows the delimited maritime boundary between Australia and Timor-Leste under the 2018 treaty.

As explained in Figure 3, whereas the Philippines v. China arbitration fits into phase 2 of the dispute settlement scheme, the Timor-Leste v. Australia proceeding falls into phase 3-compulsory conciliation with a nonbinding outcome. This is because the Philippines litigated on the basis of "maritime entitlements." In contrast, Timor-Leste disputed "maritime boundaries" - an area that is already excluded from compulsory binding procedures since Australia has made a declaration under UNCLOS Article 298. In its notice of conciliation, Timor-Leste chose this option because it was "the only

\section{FIGURE 4}

Joint Petroleum Development Area within the Timor Sea

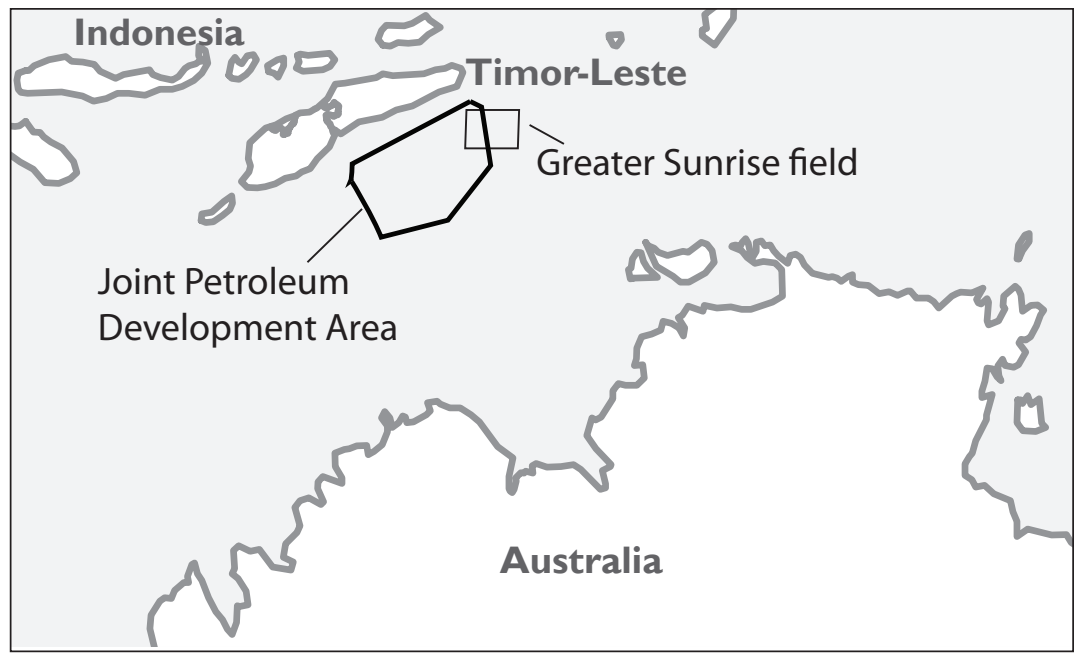

Source: Based on Department of Foreign Affairs and Trade (Australia), "Australia's Maritime Arrangements with Timor-Leste," https://www.dfat.gov.au/geo/timor-leste/australias-maritime-arrangements-with-timor-leste.

Note $\curvearrowright$ This map is for representational and illustrative purposes only and does not represent accurate geographic boundaries and maritime lines.

43 PCA, “Timor Sea Conciliation (Timor-Leste v. Australia),” PCA case no. 2016-10, May 9, 2018 \& https://pca-cpa.org/en/cases/132. 
procedure available to it" for maritime delimitation with Australia. ${ }^{44}$ In short, Timor-Leste was precluded from other dispute resolution options thanks to Australia's own Article 298 declaration.

Upon the launch of conciliation, each party to a dispute is requested to appoint two conciliators to the UN Conciliation Commission; the fifth and final member is appointed by the first four. Unlike China's nonacceptance and nonparticipation in the South China Sea arbitration, Australia engaged in the conciliation proceedings in good faith after its objection to the competence of the commission was dismissed. ${ }^{45}$ By appointing two conciliators, Australia indicated its participation.

It is worth noting that the list of conciliators provided by UNCLOS was only for reference, as both Timor-Leste and Australia were able to

\section{FIGURE 5}

The Maritime Boundary Delimited between Australia and Timor-Leste under the 2018 Treaty

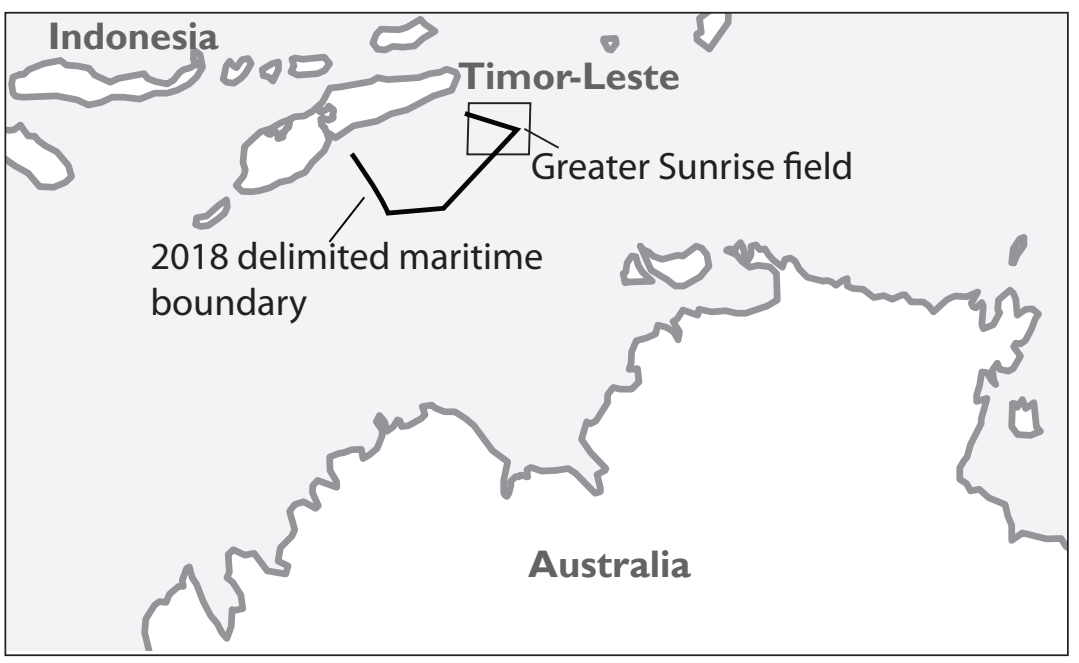

Source: Based on Department of Foreign Affairs and Trade (Australia), "Australia's Maritime Arrangements with Timor-Leste," https:/www.dfat.gov.au/geo/timor-leste/australias-maritime-arrangements-with-timor-leste.

Note $\approx$ This map is for representational and illustrative purposes only and does not represent accurate geographic boundaries and maritime lines.

44 PCA, “Timor Sea Conciliation (Timor-Leste v. Australia), Annex 3: Notice of Conciliation” $\diamond$ https://pcacases.com/web/sendAttach/2331.

45 PCA, “Timor Sea Conciliation (Timor-Leste v. Australia), Annex 10: Letter from Australia to the Commission of 22 September 2016" $\approx$ https://pcacases.com/web/sendAttach/2338. 
appoint conciliators not on the list. ${ }^{46}$ Although the PCA was also chosen as the forum for conciliation proceedings, its role was quite limited in facilitating the negotiations and settlement process. Instead, the Conciliation Commission played a critical role in engaging the disputing parties; putting forth confidence-building measures, options, and ideas; and producing a nonbinding report that included recommendations and conclusions upon which the parties could negotiate an agreement. ${ }^{47}$ Equally important is how the Conciliation Commission, unlike the PCA, was able to consider nonlegal factors such as the political and economic issues at stake. This highlights the flexibility of conciliation proceedings as much as it raises questions about the applicability of international law. ${ }^{48}$

Despite leading to a successful maritime boundary agreement, the conciliation process did not achieve a breakthrough on the crucial "development concept" for the Greater Sunrise gas field and the destination of its pipeline, since the boundaries agreed to are largely irrelevant and even misleading. ${ }^{49}$ Although under the 2018 treaty a significant portion of Greater Sunrise resides in Timor-Leste's maritime boundary (Figure 5), the state does not have sole ownership nor jurisdiction over the area because it is subject to joint development.

Unresolved issues aside, there are lessons to be gleaned from the conciliation's success, such as the importance of trust-building and willing participation and commitments from the disputing parties, as well as the flexibility granted to the Conciliation Commission. The settlement was amicable thanks to the commission's de-emphasis of legal positions in maritime delimitation and its suggested focus on economic interests. ${ }^{50}$ In other words, delimiting boundaries was secondary to reaching a consensus in the Greater Sunrise area, and the more important result was not the finalized delimitation based on Timor-Leste's equidistance argument but revenue sharing and a pipeline development plan. Though future development of the

\footnotetext{
46 PCA, "Timor Sea Conciliation (Timor-Leste v. Australia), Annex 1: The Parties' Representatives” \& https://pcacases.com/web/sendAttach/2329.

47 PCA, “Timor Sea Conciliation (Timor-Leste v. Australia), Annex 12: Commission's Proposal on Confidence-Building Measures of 14 October 2016" $\sim$ https://pcacases.com/web/sendAttach/2340.

48 Sienho Yee, "Conciliation and the 1982 U.N. Convention on the Law of the Sea," Ocean Development and International Law 44, no. 4 (2013): 315-34; and Dai Tamada, "The Timor Sea Conciliation: The Unique Mechanism of Dispute Settlement," European Journal of International Law 31, no. 1 (2020): 321-44.

49 Rebecca Strating, “The Timor Sea Disputes: Resolved or Ongoing?” Australian Institute of International Affairs, March 9, $2018 \sim$ https://www.internationalaffairs.org.au/australianoutlook/ the-timor-sea-disputes-resolved-or-ongoing.

50 Tamada, "The Timor Sea Conciliation."
} 
field is still uncertain, the revenue-sharing ratio in the Greater Sunrise field will be $20 \%$ Australia and $80 \%$ Timor-Leste if the pipeline goes to the former, or $30 \%$ and $70 \%$ if it goes to the latter. ${ }^{51}$

\section{Implications}

Three points are made abundantly clear in the preceding case studies. First, given that a lawsuit can take years to conclude, the applicant must set its priorities straight and subsequently adopt the most appropriate legal approach. Because it wanted an international tribunal to rule on the legality of China's claims and activities in the South China Sea and to ascertain the status of certain features within the sea, the Philippines chose compulsory arbitration entailing binding decisions. Because Australia made a declaration under Article 298 when it wanted a permanent maritime boundary settlement, Timor-Leste had to pursue compulsory conciliation entailing nonbinding decisions.

Second, the competition for hydrocarbon resources in disputed areas often looms large in dispute negotiation and settlement. In the Timor Sea case, the maritime boundary issue was temporarily resolved following a revenue-sharing agreement, but this could only happen because there was reliable information on hydrocarbon resources. Setting aside multiparty complications in the South China Sea, the hydrocarbon reserves in the disputed area are not fully discovered and remain largely estimated-190 trillion cubic feet of natural gas and 11 billion barrels of oil. ${ }^{52}$ This alone presents a major hurdle to the formulation of a feasible benefit-sharing scheme.

Third, the negotiation and eventual conclusion of an agreement depends greatly on the political will of the involved parties. In the Timor Sea conciliation, Timor-Leste had a negotiating partner that accepted the Conciliation Commission's jurisdiction and engaged with the process in good faith by carrying out its commitments. By contrast, in the South China Sea disputes and arbitration, China has not been a willing participant in negotiating regional agreements. Nearly twenty years have passed since the DOC was signed by China and members of ASEAN, but a binding code of conduct is still not finalized. Trust-building is critical considering that, despite

51 PCA, "Timor Sea Conciliation (Timor-Leste v. Australia), Annex 28: Treaty Signed by the Parties on 6 March 2018" $\approx$ https://pcacases.com/web/sendAttach/2356; and David Hutt, "Timor-Leste's Costly Oil and Gas Ambitions Grind to a Halt," Diplomat, October 2, $2020 \approx$ https://thediplomat. com/2020/10/timor-lestes-costly-oil-and-gas-ambitions-grind-to-a-halt.

52 Asia Maritime Transparency Initiative, "South China Sea Energy Exploration and Development" https://amti.csis.org/south-china-sea-energy-exploration-and-development. 
sharing Communist ideologies, Vietnam and China still harbor mistrust over each other's intentions. ${ }^{53}$ Given China's growing militarized presence in the South China Sea, Hanoi is skeptical that its claims would be respected and protected in any negotiations with Beijing. Similarly, China wants to keep the dispute a regional matter that can be settled only among the claimants and is wary of Vietnam building closer ties with the United States and Japan, thereby involving nonclaimant third parties in the dispute. In essence, mistrust and misperceptions persist because neither side has managed to assure the other of its peaceful intentions.

\section{VIETNAM: WHICH LEGAL PATH FORWARD?}

The two cases examined above suggest that if Vietnam were to build a case, following a path similar to that of the Philippines rather than Timor-Leste would be more practical. While Annex V, Article 3(g) does allow multiparty conciliation, initiating a case that involves other claimant states would present complications given the intertwining economic and geopolitical interests in the South China Sea. Thus, Hanoi would need to carefully craft a case to seek a ruling on (1) Vietnam's maritime entitlements under UNCLOS and (2) the legality of China's claims and activities in waters within Vietnam's 200-nautical-mile EEZ and continental shelf.

\section{Tribunal Jurisdiction}

For an arbitration to move forward, preconditions with regard to the tribunal's jurisdiction and the case's admissibility must be satisfied. Figure 6 lays out three primary questions that must be answered for a compulsory procedure with binding decisions.

First, just as the Philippines had to prove that all attempts to negotiate and settle the dispute with China in the South China Sea had failed or become futile over the years, Vietnam must also present concrete evidence. This matter pertains to Part XV, Section 1, on dispute settlement, which stresses the need for parties to pursue a traditional, consent-based route of dispute negotiation and settlement (see phase 1 in Figure 2). It is arguably more difficult for Vietnam to prove this point given that, in numerous bilateral meetings and joint statements with China, both sides have agreed to manage

\footnotetext{
53 Quan-Hoang Vuong et al., “The 'Same Bed, Different Dreams' of Vietnam and China: How (Mis)trust Could Make or Break It,” European Journal of East Asian Studies 18, no. 1 (2019): 93-128.
} 
FIGURE 6

Three Questions Concerning the Determination of Jurisdiction and Admissibility for Any Court or Tribunal Constituted under UNCLOS
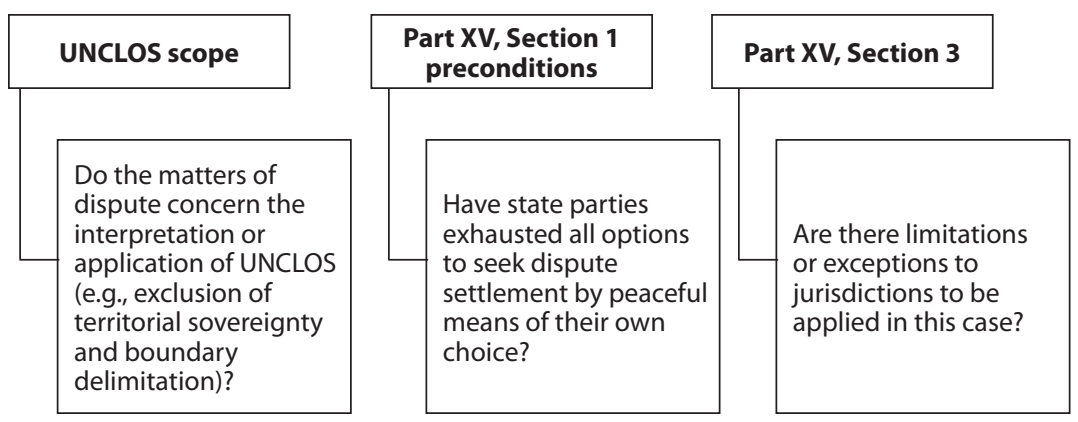

and control their differences concerning maritime issues as well as maintain peace and stability in the South China Sea in compliance with the 2002 DOC. Additionally, the two sides have already reached an important consensus on maritime issues as well as a six-point pact signed in 2011 on basic principles guiding the settlement of sea-related issues. ${ }^{54}$ In particular, as part of the six-point agreement, the third point explicitly states that "[f]or sea-related disputes between Vietnam and China, the two sides shall solve them through friendly talks and negotiations. Disputes relating to other countries shall be settled through negotiations with other concerned parties." In fact, the two sides have held regular talks on cooperation in less sensitive sea-related areas, with the latest round having taken place on November 19-20, 2019.55

Thus, the challenge for Vietnam is to prove that, as of 2021, (1) existing bilateral agreements to settle disputes through peaceful negotiations are failing, (2) all peaceful options have been exhausted, and (3) no existing agreement excludes any means of third-party settlement. As part of this process, it is up to the tribunal to determine whether the 2011 bilateral agreement on basic principles guiding the settlement of maritime issues constitutes a legally

\footnotetext{
54 "VN-China Basic Principles on Settlement of Sea Issues," Vietnam Plus, October 12, 2011 \& https://en.vietnamplus.vn/vnchina-basic-principles-on-settlement-of-sea-issues/31776.vnp.

55 "VN, China Hold Talks on Less Sensitive Marine Cooperation Areas," Viet Nam News, November 21, $2019 \approx \mathrm{https}: / /$ vietnamnews.vn/politics-laws/548746/vn-china-hold-talks-on-less-sensitivemarine-cooperation-areas.html\#ETSyJYyhGGxm9wwo.97.
} 
binding document or whether it is "political and aspirational in nature." 56 Similar to the reasoning on the award in the Philippines v. China case, Vietnam can reasonably argue that the 2011 agreement and subsequent bilateral talks have reiterated the two sides' commitments to the "legal regime and principles defined by international law, including the 1982 UNCLOS." ${ }^{57}$ Given the tribunal's precedent ruling in the South China Sea arbitration case, any arguments by China regarding its insistence and preference for bilateral negotiations cannot negate the other party's right to other means of dispute settlement recourse as per Part XV, Section 2.58

Second, Vietnam should clarify at all stages of the proceeding that its concern lies not with a ruling on territorial sovereignty and maritime boundary delimitation (due to China's 2006 declaration pursuant of Article 298 on exceptions to the applicability of Part XV, Section 2). In selecting a forum for dispute settlement, PCA arbitration is the default option if there are no conflicting selections as per Article 287(5). As a tribunal from UNCLOS has no legal authority to determine territorial sovereignty, it only adjudicates on disputes arising under the convention and is thus restricted to the maritime entitlements, legal rights, and obligations of parties to the convention. By emphasizing its rights to the living and nonliving resources within its EEZ and continental shelf, Vietnam can make clear that the dispute concerns the interpretation and application of UNCLOS.

Third, in seeking a tribunal ruling on the lawfulness of China's activities in the South China Sea, particularly in Vietnam's EEZ and continental shelf, Hanoi should bear in mind that UNCLOS Article 298 excludes disputes concerning either military or law-enforcement activities related to marine scientific research or fisheries. Here, the Philippines' argument in the merits stage of arbitration is worthy of note. In its case, the Philippines argued that the exception of military activities should not apply because China does not characterize its own activities as military in nature. Citing official Chinese statements on various occasions affirming that China's activities at Mischief

\footnotetext{
56 PCA, “The South China Sea Arbitration (The Republic of Philippines v. The People's Republic of China), Award on Jurisdiction and Admissibility."

57 "VN-China Basic Principles on Settlement of Sea Issues,"; and PCA, "The South China Sea Arbitration (The Republic of Philippines v. The People's Republic of China), Award on Jurisdiction and Admissibility."

58 In addition, Vietnam can also refer to the Mox Plant case (Ireland v. United Kingdom) and the Arctic Sunrise case (Netherlands v. Russia), in which the claimant states and the tribunal give justification for third-party dispute settlement.
} 
Reef were for civilian purposes, the tribunal ruled that Article 298 indeed did not apply. ${ }^{59}$

Vietnam could emulate this by framing its complaint around unlawful Chinese activities in waters within its claimed EEZ and continental shelf. Since China does not characterize such activities as militaristic, its 2006 declaration to exclude disputes concerning military activity does not apply. The complaint should detail how Chinese government vessels harassed Vietnamese hydrocarbon survey operations numerous times throughout 2019 and 2020 at Vanguard Bank in the westernmost reef of the Spratly Islands, which lies within Vietnam's EEZ. ${ }^{60}$ Additionally, Vietnam can also raise questions about China's unilateral annual fishing ban in the northwestern South China Sea. While China insists that the 1995 fishing ban is necessary to "[protect] the maritime ecosystem and biodiversity from excessive fishing," ${ }^{1} 1$ it encroaches on Vietnam's EEZ. Framing the case around these issues should be acceptable to UNCLOS interpretation and application.

\section{Legal Procedures}

Based on the above considerations, this article suggests that Vietnam can reasonably make a case on its maritime entitlements under UNCLOS and question the lawfulness of China's claims and activities in waters within Vietnam's 200-nautical-mile EEZ and continental shelf. Vietnam should avoid resorting to historic claims over the territories to assert its legal stance for two reasons: (1) the PCA has already ruled on the lack of historical foundation of China's claims, and (2) no country can lawfully assert historic rights in the high seas. ${ }^{62}$ Moreover, international tribunals dealing with territory and boundary disputes have generally dismissed the evidentiary value of maps unless they carry an "intrinsic legal force," such as those embedded in a particular treaty. ${ }^{63}$

With that said, the optimal course of legal pursuit for Vietnam is to seek a formal ruling on China's violations in terms of petroleum and survey

59 PCA, “The South China Sea Arbitration (The Republic of Philippines v. The People's Republic of China), Award."

60 Drake Long, “China’s Coast Guard Shows Up at Vanguard Bank Again,” Radio Free Asia, July 7, $2020 \curvearrowright$ https://www.rfa.org/english/news/china/vietnam-southchinasea-07072020183440.html.

61 Liu Caiyu and Cao Siqi, "Lifting Fishing Ban 'Won't Escalate Regional Tensions," Global Times, August 17, $2020 \approx$ https://www.globaltimes.cn/content/1198031.shtml.

62 Renato Cruz De Castro, “The 12 July 2016 Permanent Court of Arbitration's (PCA) Award: The Philippines' Lawfare versus China's Realpolitik in the South China Sea Dispute," International Journal of China Studies 8, no. 3 (2017): 347-72.

63 Miyoshi, "China's 'U-Shaped Line' Claim in the South China Sea." 
activities, fishing activities, and freedom of navigation. As discussed above, in its submissions to the CLCS on an extended continental shelf, Vietnam has consistently measured the continental shelf's outer limit from the coastal mainland and held that no features in the Spratly Islands are capable of generating an EEZ or continental shelf. If the tribunal were to rule in favor of Vietnam's entitlement to an EEZ and continental shelf based on its extensive coastline, the award would ascertain Vietnam's sovereign rights and offshore jurisdiction in the area.

Additionally, although Vietnam did not intercede in the Philippines-China arbitration case, it did send a note verbale to the tribunal on December 5, 2014, in which it raised five points: (1) full observance and implementation of the convention's rules and procedures, (2) preservation of Vietnam's legal rights and interests, (3) understanding of subject matter not under the tribunal's jurisdiction, (4) protest and rejection of China's nine-dash line, and (5) support for the tribunal's legal competence and reservation of Vietnam's right to intervene if appropriate and in accordance with international law. ${ }^{64}$ Many of the aforementioned points were not new. Even though Vietnam reserved its right to intervene, it has never done so and remained only as an observer state in the arbitration.

UNCLOS also provides the option for nonbinding compulsory conciliation under Annex V if a party opts out of compulsory procedures. As previously discussed, this clause has been only invoked once in the Timor Sea case. ${ }^{65}$ While disputing parties in a conciliation do not necessarily have to pick conciliators from the list of conciliators and arbitrators nominated under Article 2 of Annexes V and VII, reviewing the latest list shows that to date China has not nominated anyone, while Vietnam nominated four conciliators and four arbitrators in May 2020. ${ }^{66}$ This move opens up speculation about whether Vietnam will take legal action, such as initiating a nonbinding compulsory conciliation with China compatible with UNCLOS. Nonetheless, the Timor Sea conciliation indicates the importance of the parties' political will in the conciliation process, a matter that may be extremely challenging in the South China Sea context. Overall, considering that China could refuse to participate in a case instituted by Vietnam, it is more practical for

\footnotetext{
64 PCA, "The South China Sea Arbitration (The Republic of Philippines v. The People's Republic of China), Award on Jurisdiction and Admissibility."

65 PCA, "Timor Sea Conciliation (Timor-Leste v. Australia)."

66 United Nations, "Viet Nam: Nomination of Arbitrators and Conciliators under Annexes V and VII of the Convention," May 15, $2020 \approx$ https://reaties.un.org/doc/Publication/CN/2020/ CN.168.2020-Eng.pdf.
} 
Hanoi to avoid maritime delimitation issues and instead focus on maritime entitlements. This is because, under UNCLOS, China's nonparticipation does not bar proceedings, though this could affect the implementation of the ruling. As a party to UNCLOS, China is bound under international law by any awards rendered by the tribunal. Therefore, its refusal to comply with the ruling would further undermine its international credibility.

\section{CONCLUSION}

By examining the PCA ruling on the Philippines-China case and the Timor-Leste-Australia conciliation, this article shows that Vietnam has a viable legal path. The legal options presented have accounted for the practical challenges of proving the case suitable to proceed under the form of compulsory procedures with binding decisions. In fact, the decision to consider pursuing a legal course of action against China was mentioned by Vietnamese deputy foreign minister Le Hoai Trung at a press conference in Hanoi in November 2019. In referring to the applicability of UNCLOS, Trung acknowledged Vietnam's awareness of measures such as "fact-finding, mediation, conciliation, negotiation, arbitration and litigation measures."67

From this review of UNCLOS rules and relevant cases, it is clear that even though China has become the Asia-Pacific's dominant power, ignoring the possibility of legal proceedings by other nation-states in the region might do more harm than good. As a signatory to UNCLOS, China risks forfeiting its lawful rights to seek justice by virtue of its nonparticipation. Nonetheless, even if China were to refuse to participate in the legal challenge and abide by subsequent verdicts, any decision by Vietnam to pursue its maritime rights under UNCLOS would be momentous for the dispute itself, the role of international law in maritime disputes, and regional geopolitics. $\diamond$

67 James Pearson and Khanh Vu, "Vietnam Mulls Legal Action over South China Sea Dispute," Reuters, November 6, $2019 \approx$ https://www.reuters.com/article/us-vietnam-southchinasea/ vietnam-mulls-legal-action-over-south-china-sea-dispute-idUSKBN1XG1D6. 
